\title{
Harmonic response analysis of an impeller of a gas turbine engine which modelled by using high entropy alloy materials
}

\author{
Yüksek entropi alaşımlı malzemeler ile modellenen bir gaz türbini çarkının harmonik tepki \\ analizi
}

\author{
Serkan GÜLER*1,a \\ ${ }^{1}$ Iskenderun Technical University, Faculty of Engineering and Natural Sciences, Department of Mechanical Engineering, 31200, \\ Hatay, Turkey
}

• Geliş tarihi / Received: 02.03.2021 • • Düzeltilerek geliş tarihi / Received in revised form: 22.10.2021 • Kabul tarihi / Accepted: 27.10 .2021

\begin{abstract}
One of the problems in a gas turbine's impeller design is to predict the frequency-stress response caused by the harmonic force resulted from the unbalanced mass. To avoid from impeller's flaws that may occur, designers must essentially determine the stress conditions of machinery parts under high-speed rotations. The present research explores, for the first time, the effects of modelling with high entropy alloy materials for an impeller of a gas turbine engine on harmonic responses. In order to conduct harmonic analysis, a finite element model established for an impeller of gas turbine engine by using commercial Ansys finite element package. In the finite element model, the impeller and its shaft modelled by using solid elements and beam elements, respectively. The influence of materials having different high entropy alloys on stress responses is examined for an impeller of a gas turbine engine. The results show that the highest stress exists in $\mathrm{AlCoCrFeNi}$ high entropy alloy material for along the sweep frequency range. In addition, the highest stress-percentage ratio is in $\mathrm{CoCrFeNi}$ high entropy alloy material for first resonance frequencies. Also, computations illustrate the

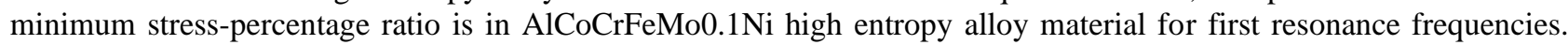
Another finding is that the maximum percentage ratio is in $\mathrm{CoCrFeNi}$ high entropy alloy material for second resonance frequencies. Furthermore, the lowest percentage ratio is detected in AlCoCrFeMo0.1Ni high entropy alloy material for second resonance frequencies.
\end{abstract}

Keywords: Finite element method, Harmonic analysis, High entropy alloys, Vibration

\section{$\ddot{O_{z}}$}

Bir gaz türbininin çark tasarımındaki sorunlardan biride dengesiz kütleden meydana gelen harmonik kuvvetin sebep olduğu frekans-gerilme cevabını tahmin etmektir. Oluşabilecek çark kusurlarından kaçınmak için tasarımcılar temel olarak makine parçalarının yüksek hız altındaki gerilme şartlarını belirlemelidirler. Bu araştırma, bir gaz türbini motorunun çarkı için yüksek entropi alaşımlı malzemelerle modellemenin harmonik tepkiler üzerindeki etkilerini ilk kez incelemektedir. Harmonik analizleri gerçekleştirmek için ticari Ansys sonlu eleman paketi kullanılarak bir gaz türbini motorunun bir çarkı için bir sonlu eleman modeli oluşturulmuştur. Sonlu eleman modelinde çark ve şaft sırasıyla katı ve kiriş sonlu elemanları kullanılarak modellenmiştir. Bir gaz türbini motorunun çarkı için farklı yüksek entropi alaşımlarına sahip malzemelerin stres tepkileri üzerindeki etkisi incelenmiştir. Sonuçlar en yüksek gerilimin, tarama frekansı aralı̆̆ boyunca AlCoCrFeNi yüksek entropi alaşıml malzemede mevcut olduğunu göstermektedir. Ek olarak birinci rezonans frekansları için en yüksek gerilim-yüzde oranı CoCrFeNi yüksek entropi alaşımlı malzemededir. Ayrıca hesaplamalar birinci rezonans frekansları için minimum gerilim-yüzde oranının AlCoCrFeMo0.1Ni yüksek entropili alaşım malzemede olduğunu göstermektedir. Diğer bir bulgu ise ikinci rezonans frekanslarl için maksimum yüzde oranının CoCrFeNi yüksek entropili alaşımlı malzemede olmasıdır. Ayrıca ikinci rezonans frekansları için en düşük yüzde oranı AlCoCrFeMo0.1Ni yüksek entropi alaşımlı malzemede tespit edilmiştir.

Anahtar kelimeler: Sonlu eleman yöntemi, Harmonik analiz, Yüksek entropili alaşımlar, Titreşim

\footnotetext{
${ }^{{ }^{*} \mathrm{a}}$ Serkan GÜLER; serkan.guler@iste.edu.tr, Tel: (0326) 61356 00, orcid.org /0000-0002-1552-3432
} 


\section{Introduction \\ 1. Giriş}

Humans always have been created new materials throughout the ages by mixing alloying elements. There is a growing body of literature that recognizes the importance of high entropy alloys (Miracle \& Senkov, 2017; George et al., 2019). High entropy alloy materials provide high fracture toughness, outstanding strength, and thermal capabilities (George et al., 2019). One of the applications of high entropy alloy material is an impeller of a gas turbine (Fujieda et al., 2018). The impeller is a chief component in a gas turbine system and acts a key role in increasing the pressure and flow of fluid (Vance et al., 2010). An impeller can be exposed to dynamic loads resulting in catastrophic damages. During the design phase, preliminary estimating the frequency responses of any engineering structure is crucial to prevent undesirable damages such as crack and fatigue etc. The finite element method is an accurate method for the estimation of dynamic responses for quite different kinds of engineering structures (Rao, 2010). Within this in mind, the present study is concerned with the influences of designing with high entropy alloy materials for an impeller of a gas turbine engine on harmonic responses. Therefore, the literature review is summarized in two sections. The first part is regarding high entropy alloy materials and the second is devoted to impeller dynamics.

There are numerous studies that have documented high entropy alloys materials. Most of them are related to microstructures, mechanical properties, potential applications, and future applications (Miracle \& Senkov, 2017; George et al., 2019; Koželj et al., 2014; Youssef et al., 2014; Ye et al., 2016). Also, several studies are reported on the design of high entropy alloys materials (Erdoğan \& Zeytin, 2019; Conway, 2018; Gondhalekar, 2019; Gludovatz et al.,2014). Besides these, George et al. (2020) published a comprehensive review article on mechanical properties and deformation mechanism of high entropy alloy materials. Another article, Geanta et al. (2018) investigated the dynamic impact performance of $\mathrm{AlCrFeCoNi}$, $\mathrm{Al}_{0.8} \mathrm{CrFeCoNi}, \quad \mathrm{AlCrFeCoNi} i_{1.4}, \quad \mathrm{AlCrFeCoNi}_{1.8}$ high entropy alloy materials by experimentally and numerically. Also, Gludovatz et al., (2014) examined the low-temperature fracture behavior of $\mathrm{CrMnFeCoNi}$ high entropy alloy material. Furthermore, an inclusive material properties database of high entropy alloy materials can be found in (Gorsse et al., 2018).
A considerable amount of literature has been published on dynamics of rotating machines, gas turbines and rotordynamics (Vance et al., 2010; Bishop, 1959; Gunter, 1966; Vance \& Laudadio, 1984; Vance \& French, 1986; Ertas, 2005; Schomerus, 2007; Rao, 2011; Kumar, 2011; Gülen, 2019). Finite element analysis is used extensively to simulate rotating machinery (Rao, 2010; Kumar, 2011). Fernandes et al., (2016) presented a finite element model for performing a 3-D static fracture analysis of a gas turbine compressor blade in ANSYS software. Virdi et al., (2017) designed and analyzed an impeller in Catia and ANSYS, respectively. Oghenefejiro et al., (2018) carried out modal analysis of a gas turbine blade which modelled with both IN738 and U500 nickel-based alloy materials in ANSYS package. Mudau and Field (2018) conducted rotordynamics analysis of a turbine-generator shaft-line in ANSYS finite element environment.

This study considers the influences of modelling with high entropy alloy materials for an impeller of a gas turbine engine on harmonic responses. To perform harmonic analysis, a finite element model of the impeller has been created by using solid and beam elements in Ansys finite element package. The effects of modelling with different high entropy alloy materials on stress responses are studied.

\section{The finite element modelling of an impeller}

2. Bir çarkın sonlu eleman modeli

In this present study, harmonic analyses of an impeller modelled with different high entropy materials carried out to determine frequency responses. The finite element method is the most extensively used technique for solving engineering problems. Therefore, to accomplish frequency responses, a finite element model of the considered impeller was established. In this article, the ANSYS Workbench finite element platform was used to create a finite element model of an impeller with its shaft. The impeller was meshed with solid finite elements and the shaft is with beam finite elements. The shaft was constrained from both ends with bearing elements. The impeller and shaft rotate together as a single part. The front-view, section-view and the dimensions for the impeller are shown in Figure 1. The base and hub diameters of the impeller are $152.4 \mathrm{~mm}$ and $17.46 \mathrm{~mm}$; the exit-width and height of the impeller are $7.62 \mathrm{~mm}$ and $81.28 \mathrm{~mm}$, respectively. The shaft length is $381.28 \mathrm{~mm}$. Figure 2 displays the 3D view of the impeller. 

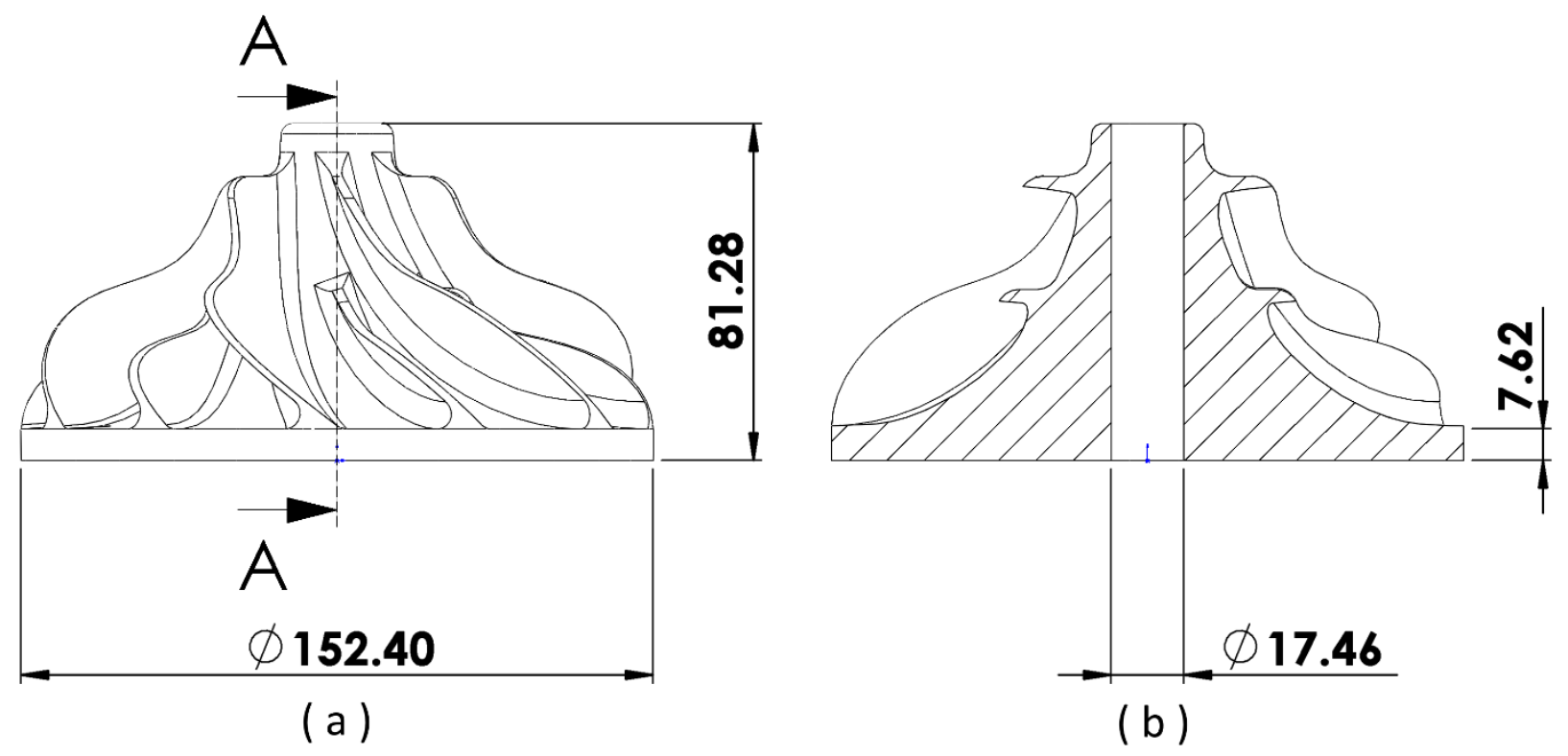

Figure 1. (a) front view and (b) A-A section view of the impeller in 2D with its essential dimensions. Şekil 1. (a) ön görünüş ve (b) Çarkın ana boyutlarlyla birlikte 2 boyutlu A-A kesit görünüşü.

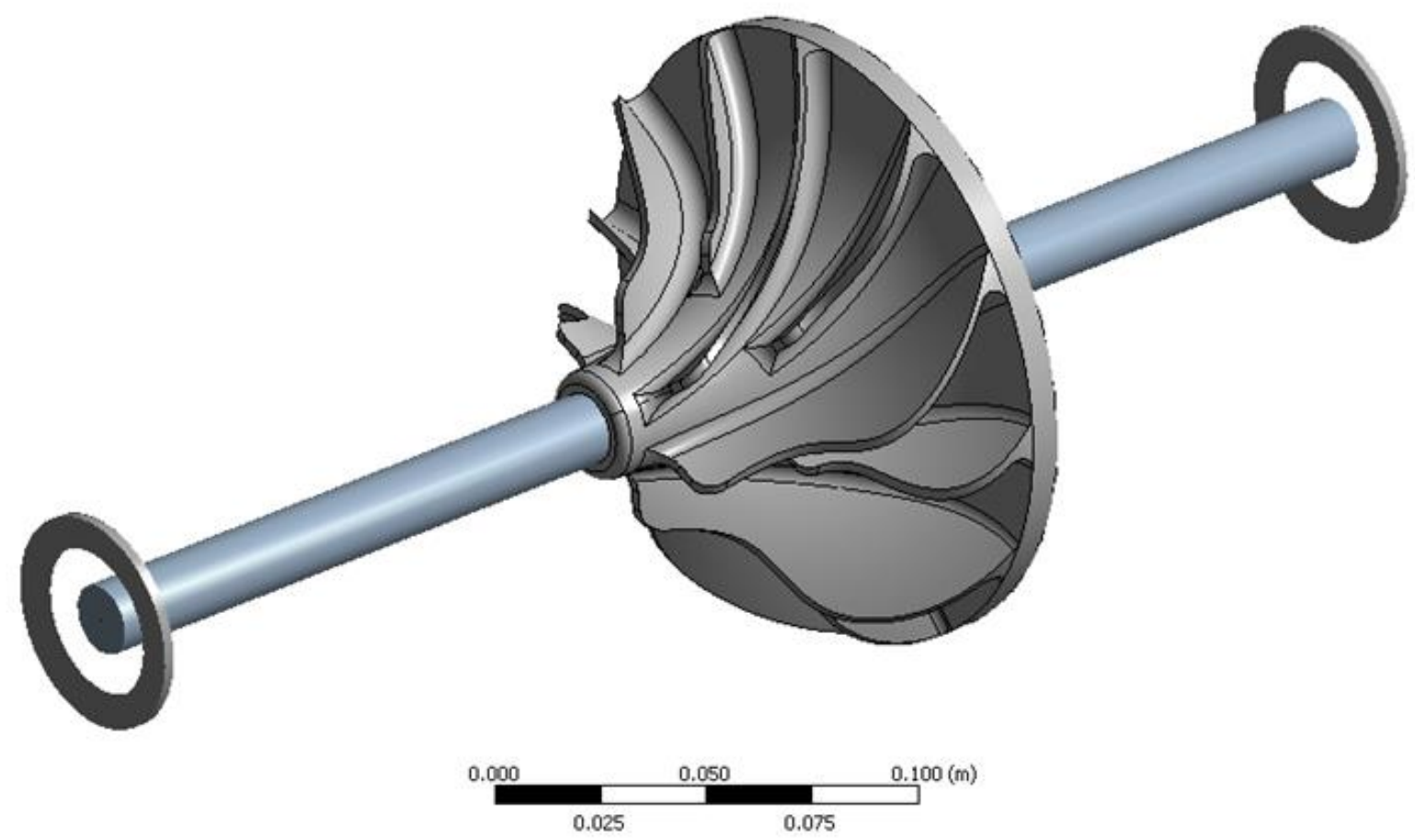

Figure 2. 3-dimensional view of the impeller.

Şekil 2. Çarkın 3-boyutlu görünüşü.

The impeller was meshed (see Figure 3) with SOLID187 which is well suited to model irregular meshes and the number of mesh is 6624 .
Additionally, the shaft was meshed with 38 number of the BEAM188 elements which are based on Timoshenko beam theory. 


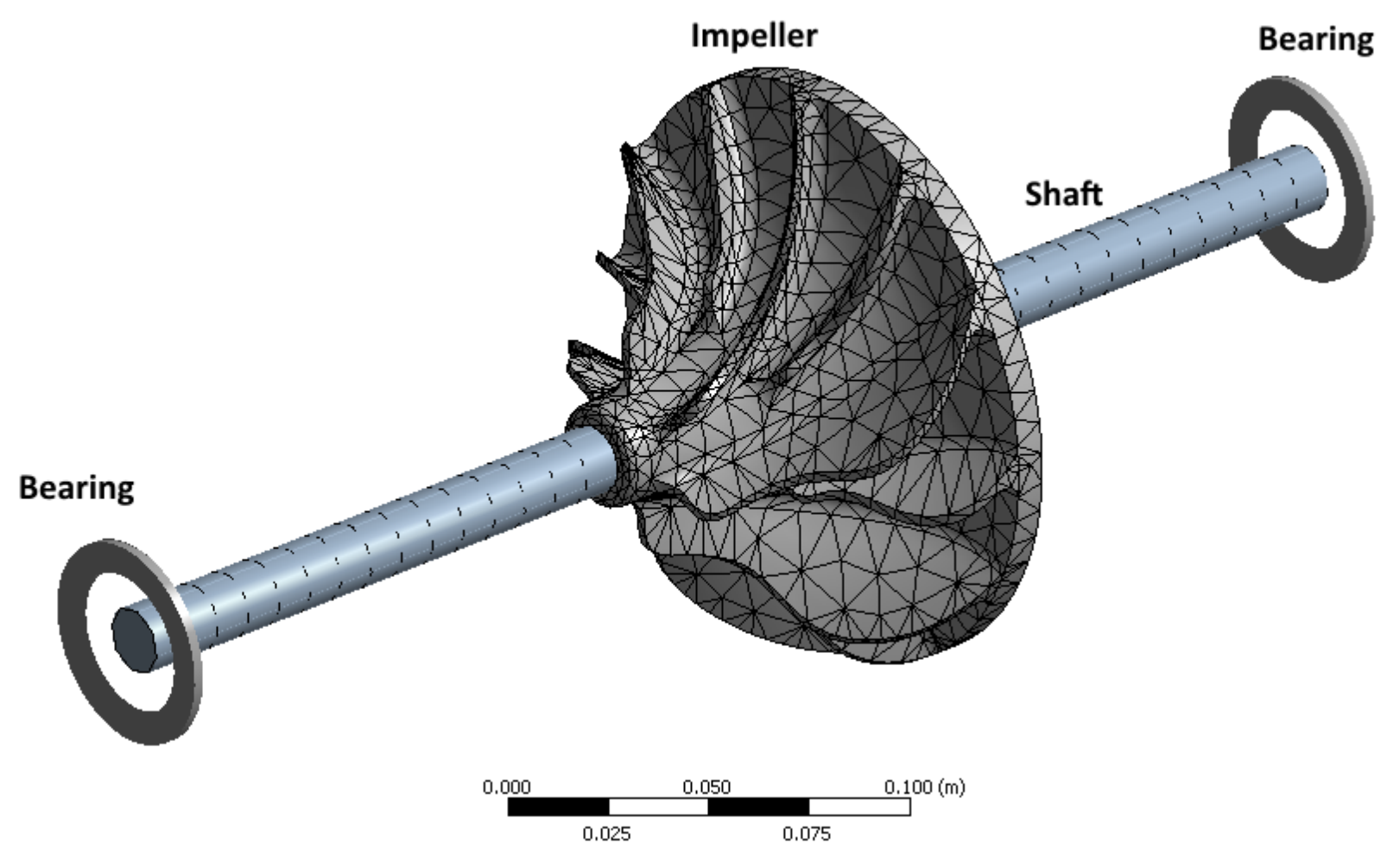

Figure 3. Finite element model of the impeller and its shaft.

Şekil 3. Çark ve milinin sonlu eleman modeli.

Baerings locations were defined both ends of the shaft and then stiffness and damping coefficients of bearings were specified by using COMBI214 element. The schematic representation of this element can be seen in Figure 4. The specified bearing properties are given in Table 1 .

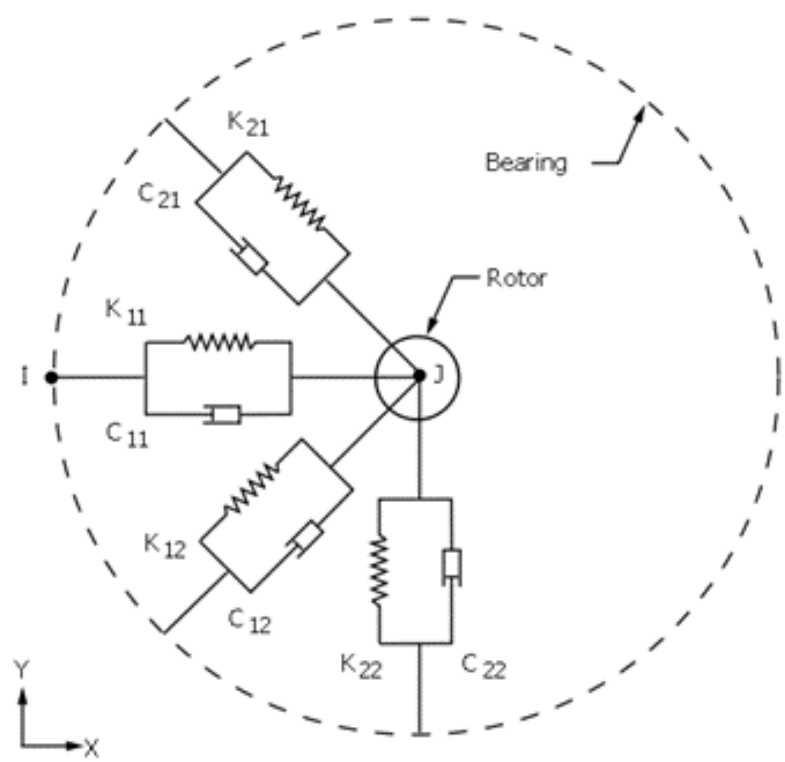

Figure 4. Schematic representation of COMBI214 element (ANSYS Release 12.1, 2010).

Şekil 4. COMBI214 elementinin şematik gösterimi (ANSYS Release 12.1, 2010).
Table 1. Properties of bearings

Tablo 1. Rulmanların özellikleri

\begin{tabular}{ll}
\hline Bearing Properties & Value \\
\hline $\mathrm{K}_{11}$ & 100000 \\
\hline $\mathrm{K}_{22}$ & 100000 \\
\hline $\mathrm{K}_{12}$ & 1000000 \\
\hline $\mathrm{K}_{21}$ & 1000000 \\
\hline $\mathrm{C}_{11}$ & 800 \\
\hline $\mathrm{C}_{22}$ & 800 \\
\hline $\mathrm{C}_{12}$ & 0 \\
\hline $\mathrm{C}_{21}$ & 0 \\
\hline
\end{tabular}

Where, $\mathrm{K}_{\mathrm{ij}}\left(\mathrm{i}=1,2 \mathrm{j}=1,2\left[\mathrm{Nm}^{-1}\right]\right)$ and $\mathrm{C}_{\mathrm{ij}}(\mathrm{i}=1,2 \mathrm{j}=1,2$ $\left[\mathrm{Nsm}^{-1}\right]$ ) denote stiffness coefficients and damping coefficients, respectively.

\section{Harmonic analysis}

3. Harmonik analiz

Harmonic analysis is an effective method to determine the steady-state response of engineering structures to loads that vary harmonically with time. Considerable theoretical knowledge of harmonic finite element analysis can be found in (Thompson et al., 2017; ANSYS Release 12.1, 2010). Therefore, the method is widely used to ascertain whether or not engineering designs will overwhelm resonance, fatigue, and other 
detrimental effects of forced vibrations. In this study, it is assumed that the harmonic force is encountered due to unbalanced mass on the impeller. The rotational velocity $(\omega)$ and unbalanced mass are represented in the model that is shown in Figure 5. The responses of the system under rotating unbalance are simulated by defining with different high entropy alloy materials. Ten different high entropy alloy materials selected from (Gorsse et al., 2018). The material properties of high entropy materials which specified in the finite element models are presented in Table 2.

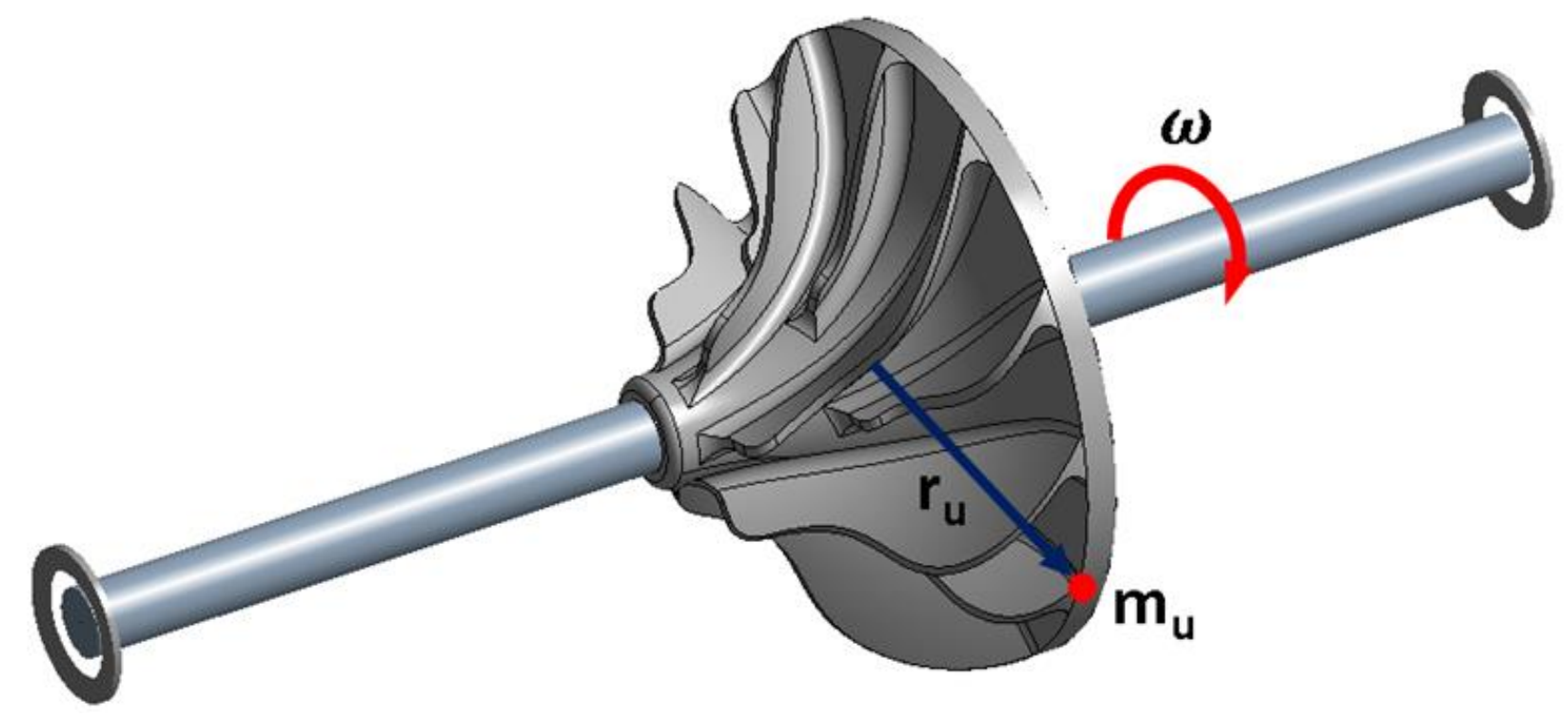

Figure 5. Unbalanced mass definition for harmonic analysis.

Şekil 5. Harmonik analiz için dengesiz kütle tanımı.

Table 2. Properties of high entropy alloy materials (Gorsse et al., 2018)

Tablo 2. Yüksek entropi alaşımlı malzemelerin özellikleri (Gorsse et al., 2018)

\begin{tabular}{llll}
$\begin{array}{l}\text { High } \begin{array}{c}\text { Entropy } \\
\text { Alloy Material }\end{array} \\
\text { CoFeNi }\end{array}$ & $\begin{array}{c}\boldsymbol{\rho} \\
{\left[\mathrm{gr} / \mathrm{cm}^{3}\right]}\end{array}$ & $\begin{array}{c}\boldsymbol{\sigma}_{\boldsymbol{y}} \\
{[\mathrm{MPa}]}\end{array}$ & $\begin{array}{c}\boldsymbol{E} \\
{[\mathrm{GPa}]}\end{array}$ \\
\hline $\mathrm{CoCrFeNi}$ & 8.5 & 211 & 207 \\
\hline $\mathrm{AlCoCrFeNi}$ & 6.2 & 148 & 225 \\
\hline $\mathrm{AlC} 0.1 \mathrm{CoCrFeNi}$ & 6.7 & 1251 & 194 \\
\hline $\mathrm{AlC} 0.2 \mathrm{CoCrFeNi}$ & 6.8 & 957 & 213 \\
\hline $\mathrm{AlC} 0.3 \mathrm{CoCrFeNi}$ & 6.8 & 867 & 151 \\
\hline $\mathrm{AlC} 0.4 \mathrm{CoCrFeNi}$ & 6.8 & 1056 & 156 \\
\hline $\mathrm{AlC} 0.5 \mathrm{CoCrFeNi}$ & 6.8 & 1060 & 181 \\
\hline $\mathrm{AlCoCrFeMo} 0.1 \mathrm{Ni} i$ & 6.8 & 1804 & 196 \\
\hline $\mathrm{AlCrFeNiMo0.5}$ & 6.8 & 1749 & 205 \\
\hline
\end{tabular}

Here, $\rho, \sigma_{y}$ and $E$ denote density, yield strength and modulus of elasticity, respectively.

The rotating unbalanced force has been calculated by using Equation 1.

$$
F_{r}=m_{u} r_{u} \omega^{2}
$$

Here, $m_{u}[k g], r_{u}[m], \omega[\mathrm{rad} / \mathrm{s}]$ and $F_{r}[k g$. $m$ ] represents unbalanced mass, location of unbalanced mass, shaft rotating speed and rotating unbalanced force, respectively. In this study, $m_{u}$ and $r_{u}$ are taken as $0.5 \mathrm{~kg}$ and $0.762 \mathrm{~m}$, respectively. The harmonic response analyses were performed in the frequency sweep of 0 to $1500 \mathrm{~Hz}$ by $5 \mathrm{~Hz}$ interval for ten finite element models established with ten different high entropy alloy materials.

\section{Results and discussions 4. Bulgular ve tartışma}

The harmonic response results are presented by using the constructed finite element model for an impeller. In order to calculate the results, the Harmonic Response Module of ANSYS Workbench finite element software was used. This module only can perform linear harmonic response analysis. In general, materials of engineering structures may undergo plastic deformation and yield before becoming fracture under the dynamic loadings. Therefore, in the design stage, predicting the elastic limits and preventing yielding are crucial issues. Von-Mises stress calculations have widely used to ascertain the yield point. However, the Harmonic Response Module does not provide Von-Mises stress versus frequency. Therefore, 
Von-Mises stresses versus the specified frequency sweep can be calculated using the normal and shear stresses computed in the harmonic analyses. These stresses are average values over the impeller. Thus,
Von-Mises stresses have been calculated by using Equation 2 (Christensen, 2013) for each of the conducted harmonic analyses.

$$
=\sqrt{\frac{1}{2}\left[\left(\sigma_{x x}-\sigma_{y y}\right)^{2}+\left(\sigma_{y y}-\sigma_{z z}\right)^{2}+\left(\sigma_{z z}-\sigma_{x x}\right)^{2}\right]+3\left(\tau_{x y}{ }^{2}+\tau_{y z}{ }^{2}+\tau_{z x}{ }^{2}\right)}
$$

The frequency response results are plotted VonMisses stresses versus frequency in the following figures (Figures 6-15). The stress and frequency units are megapascal and rpm in the figures, respectively. Yield strength limits of each high entropy alloys materials have been denoted by the red dashed line. The safety zone has been represented by green color for the impeller in Figures 6-15. Also, the Von-Misses stress values corresponding to the resonance frequencies have been given in square brackets.

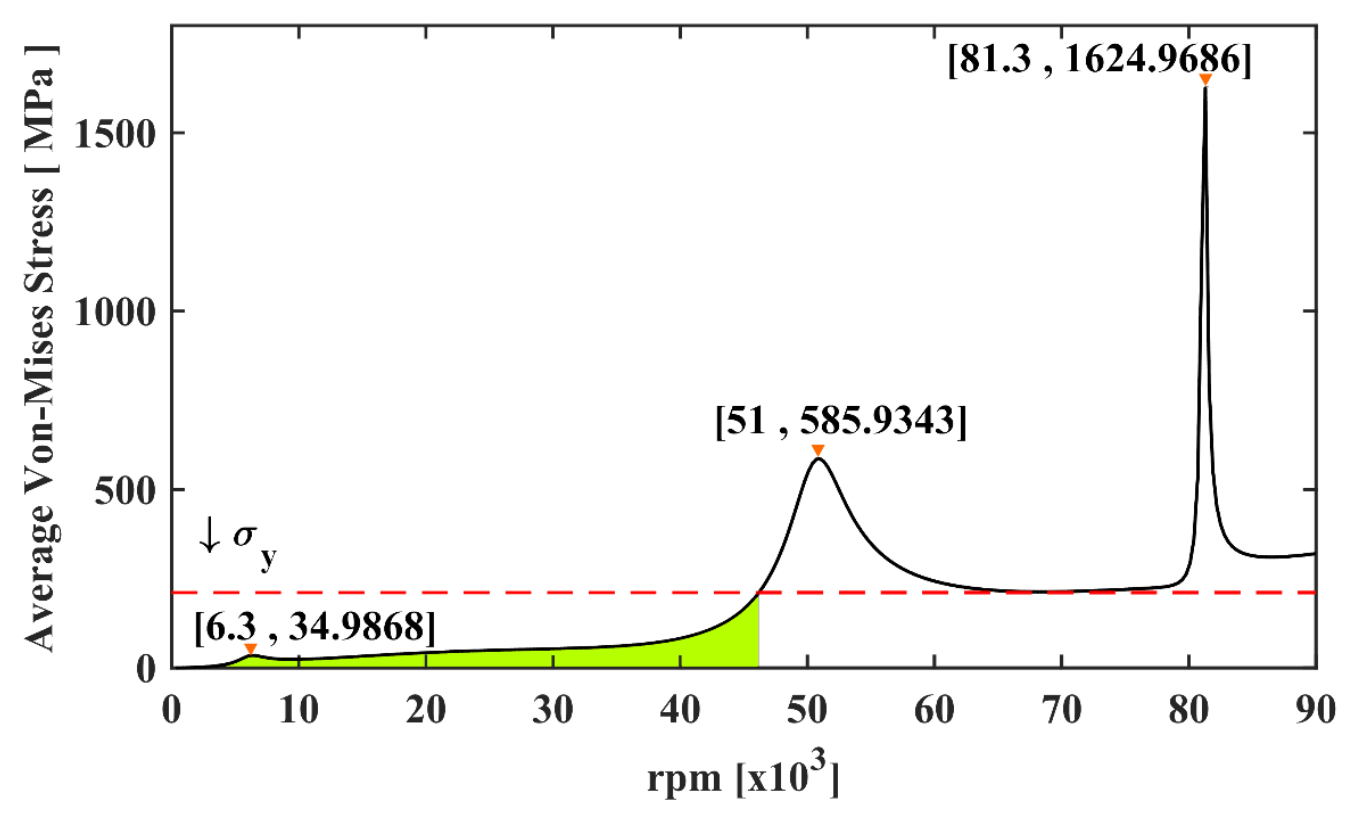

Figure 6. Shaft speed versus average Von-Mises Stress for CoFeNi.

Şekil 6. CoFeNi için şaft hızına karşıllı gelen ortalama Von-Mises Gerilmesi.

As it can be seen from Figure 6, the first resonance frequency and the stress corresponding to it are $6300 \mathrm{rpm}$ and $34.9868 \mathrm{MPa}$ for $\mathrm{CoFeNi}$ high entropy alloy material, respectively. Another finding is that the material is reliable up to the frequency $46180 \mathrm{rpm}$ that is why the impeller does not undergo plastic deformation. In other words, when the speed of the shaft is equal to or higher than $46200 \mathrm{rpm}$ the stresses are higher than the yield strength. 


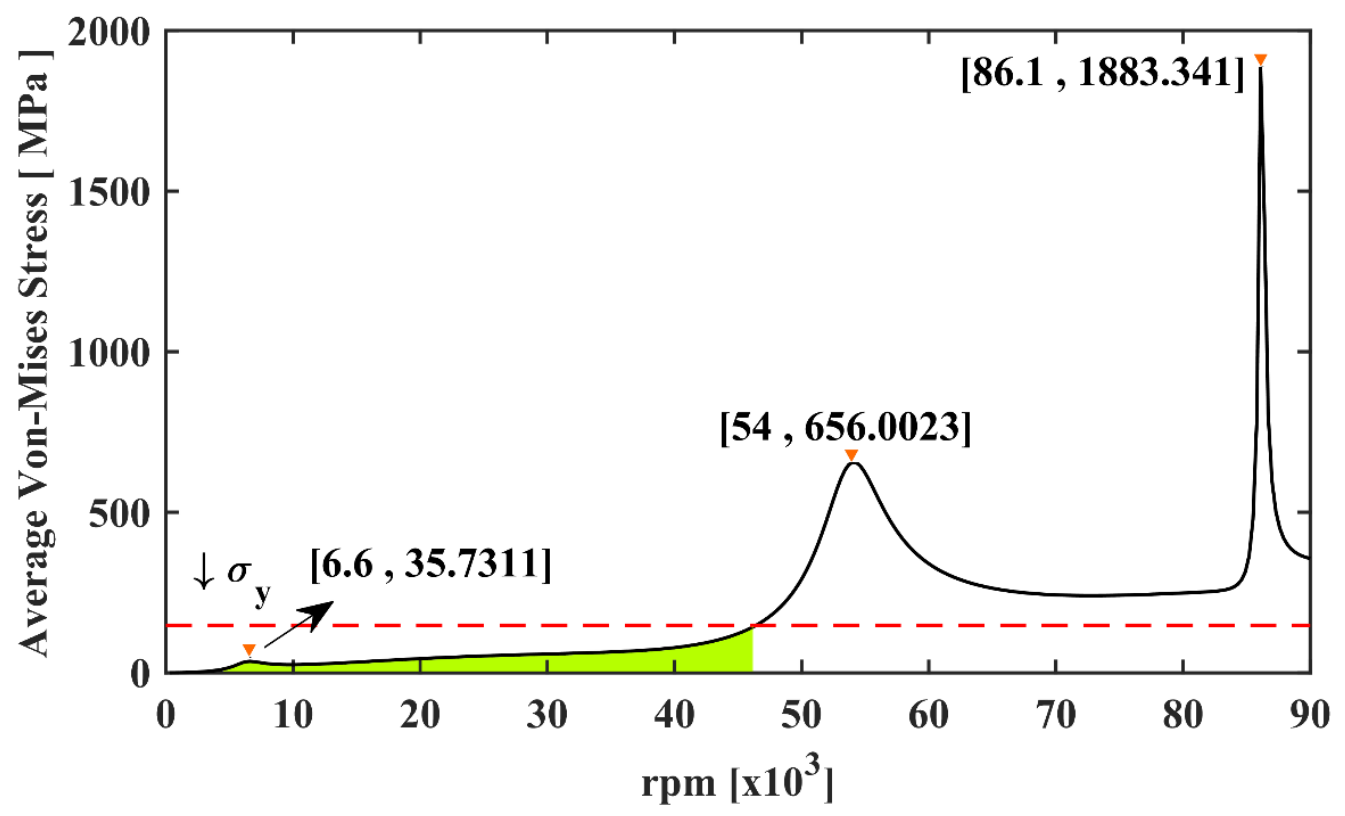

Figure 7. Shaft speed vs average Von-Mises Stress for CoCrFeNi.

Şekil 7. CoCrFeNi için şaft hızına karşılık gelen ortalama Von-Mises Gerilmesi.

According to the results from Figure 7, the first resonance frequency and the stress matching it are $6600 \mathrm{rpm}$ and $35.7311 \mathrm{MPa}$ for CoCrFeNi high entropy alloy material, respectively. As it can be inferred from the Figure 7, the impeller does not subject to plastic deformation up to the frequency $46420 \mathrm{rpm}$. In the figure, it can be seen that when the rotational speed is greater than $46420 \mathrm{rpm}$ the stresses go up over the yield strength of $\mathrm{CoCrFeNi}$ high entropy alloy material.

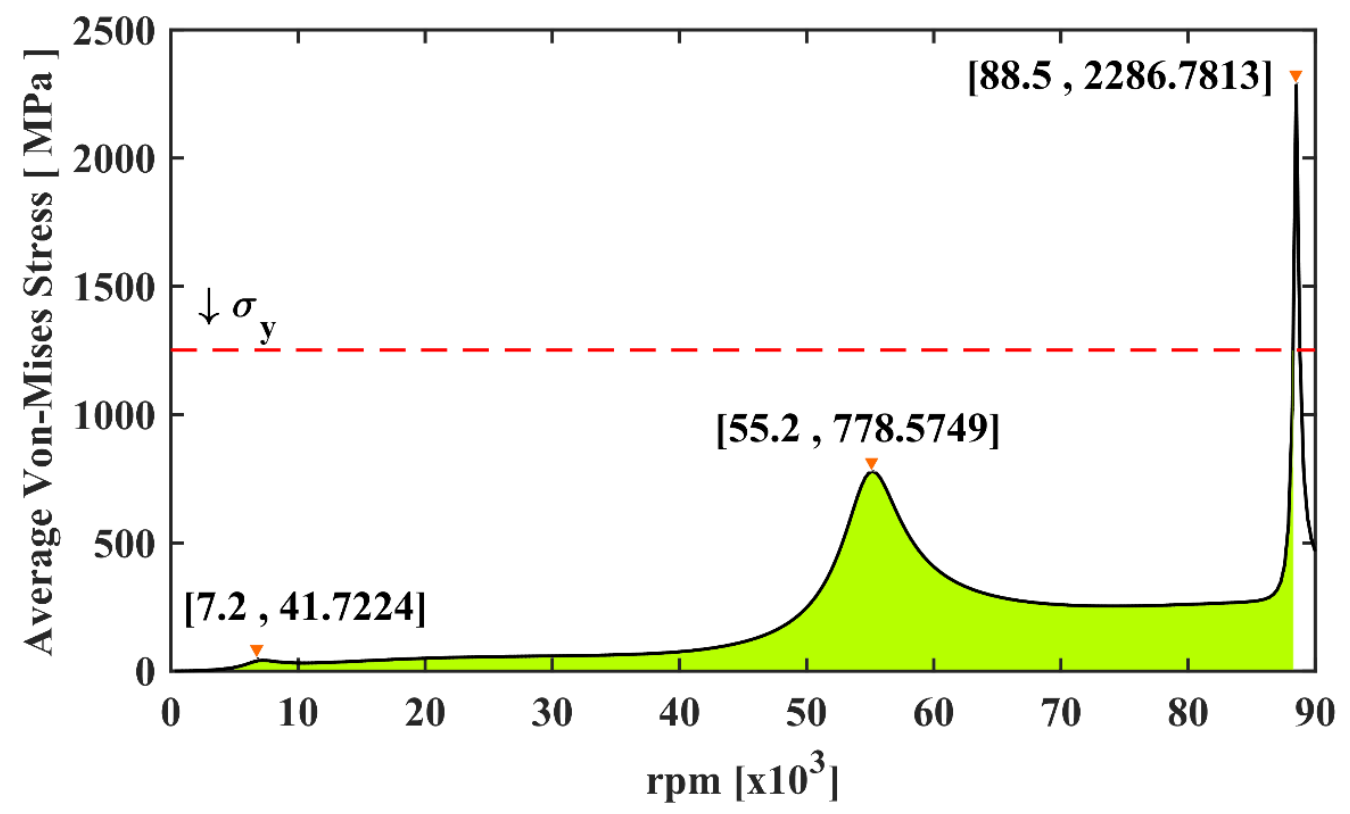

Figure 8. Shaft speed vs average Von-Mises Stress for AlCoCrFeNi.

Şekil 8. AlCoCrFeNi için şaft hızına karşıllk gelen ortalama Von-Mises Gerilmesi.

As shown in Figure 8, the first resonance frequency and the stress corresponding to it are $7200 \mathrm{rpm}$ and 41.7224 MPa for AlCoCrFeNi high entropy alloy material, respectively. From the figure above we can see that, the impeller does not undergo plastic deformation up to the frequency $88250 \mathrm{rpm}$. On the other hand, when the rotational speed is higher than $88250 \mathrm{rpm}$ the stresses rise over the yield strength of $\mathrm{AlCoCrFeNi}$ high entropy alloy material. 


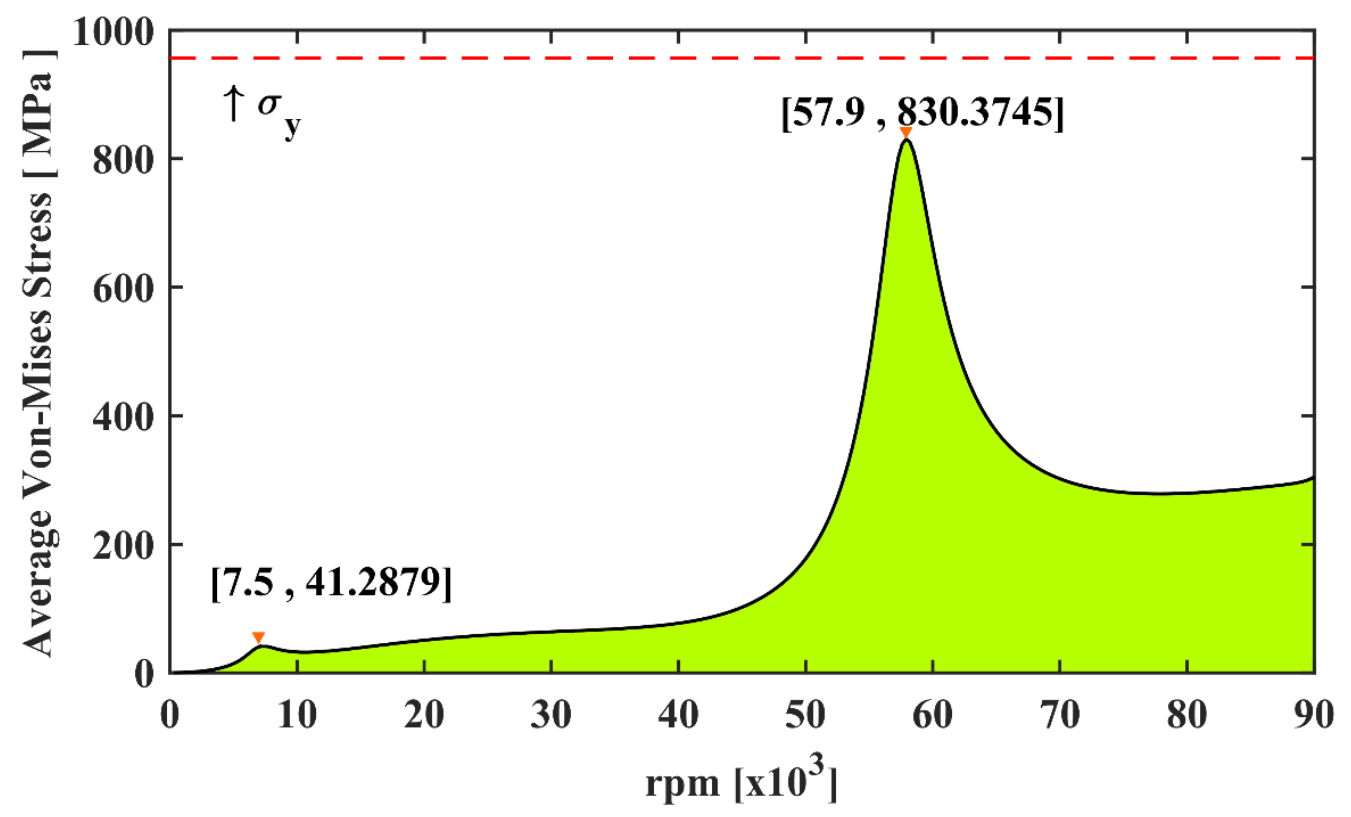

Figure 9. Shaft speed vs average Von-Mises Stress for $\mathrm{AlC} 0.1 \mathrm{CoCrFeNi}$

Şekil 9. AlC0.1CoCrFeNi için şaft hızına karşıllk gelen ortalama Von-Mises Gerilmesi

As it can be seen from Figure 9, the first resonance frequency and the stress corresponding to it are $7500 \mathrm{rpm}$ and 41.2879 MPa for AlC0.1CoCrFeNi high entropy alloy material, respectively. As shown in Figure 9, the impeller does not subject to plastic deformation up to the frequency $90000 \mathrm{rpm}$ because all stress results are under the yield strength of $\mathrm{AlC} 0.1 \mathrm{CoCrFeNi}$ high entropy alloy material. Another finding is that the impeller is reliable in the frequency sweep of 0 to $1500 \mathrm{~Hz}$ (90000 rpm).

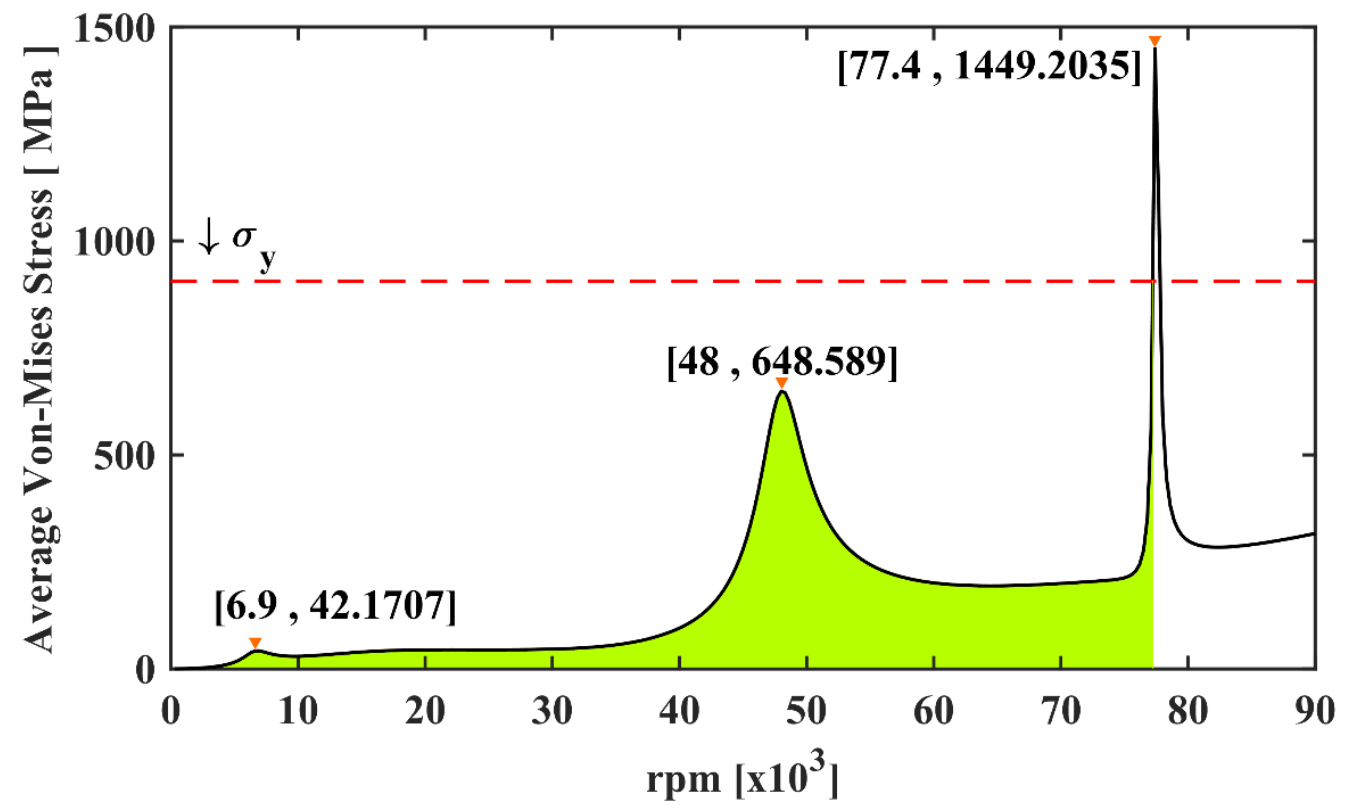

Figure 10. Shaft speed vs average Von-Mises Stress for AlC0.2CoCrFeNi

Şekil 10. AlC0.2CoCrFeNi için şaft hızına karşıllı gelen ortalama Von-Mises Gerilmesi

The Figure 10 illustrates that the first resonance frequency and the stress corresponding to it are $6900 \mathrm{rpm}$ and $42.1707 \mathrm{MPa}$ for $\mathrm{AlC} 0.2 \mathrm{CoCrFeNi}$ high entropy alloy material, respectively. As shown in Figure 10, the impeller does not subject to plastic deformation up to the frequency $77210 \mathrm{rpm}$. Also, it can be concluded that when the rotational speed is higher than $77210 \mathrm{rpm}$ the stresses arise over the yield strength of AlC0.2CoCrFeNi high entropy alloy material. 


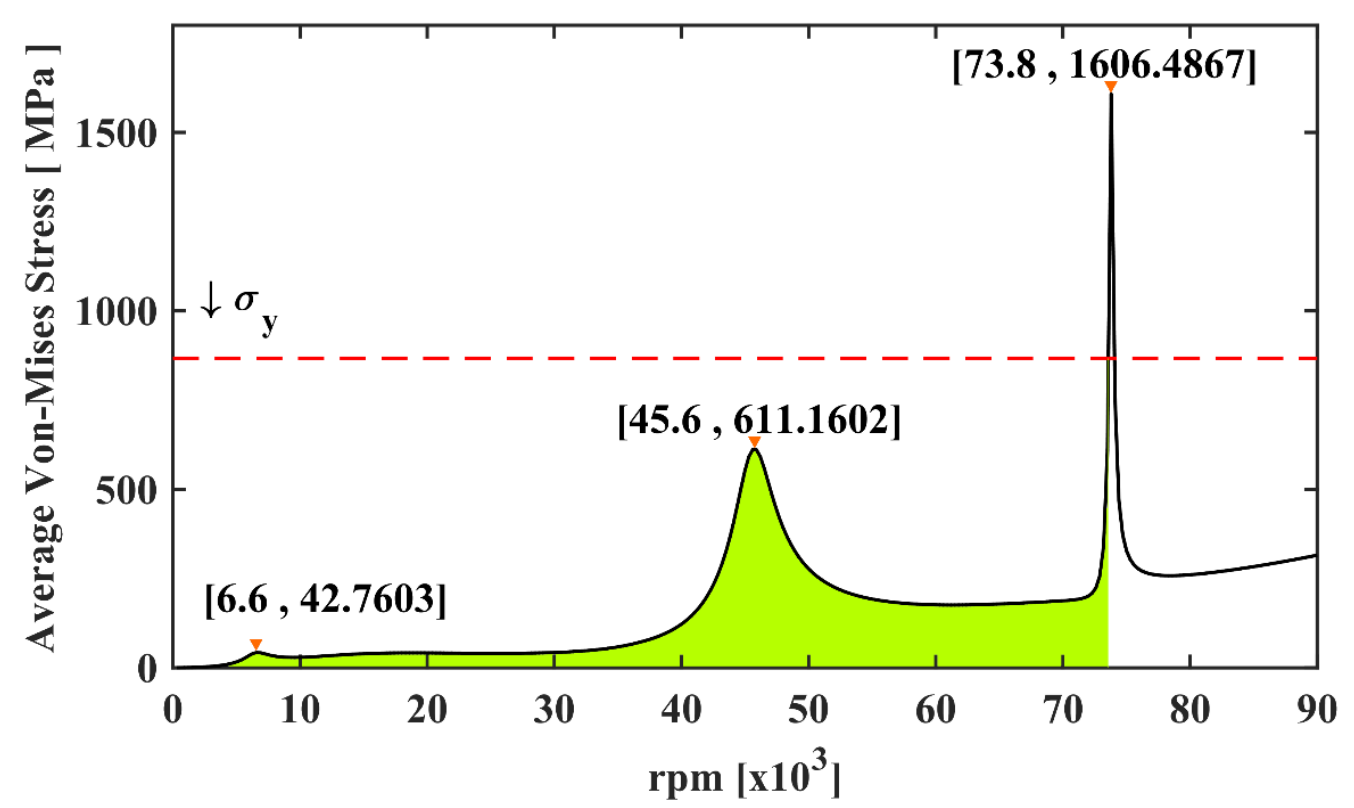

Figure 11. Shaft speed vs average Von-Mises Stress for AlC0.3CoCrFeNi

Şekil 11. AlC0.3CoCrFeNi için şaft hızına karşılık gelen ortalama Von-Mises Gerilmesi

The frequency response graph in Figure 11 shows that the first resonance frequency and the stress corresponding to it are $6600 \mathrm{rpm}$ and $42.7603 \mathrm{MPa}$ for $\mathrm{AlC} 0.3 \mathrm{CoCrFeNi}$ high entropy alloy material, respectively. From the figure above we can see that the impeller does not undergo plastic deformation up to the frequency of $73580 \mathrm{rpm}$. Also, it can be seen that when the rotational speed is higher than $73580 \mathrm{rpm}$ the stresses rise over the yield strength of $\mathrm{AlC} 0.3 \mathrm{CoCrFeNi}$ high entropy alloy material.

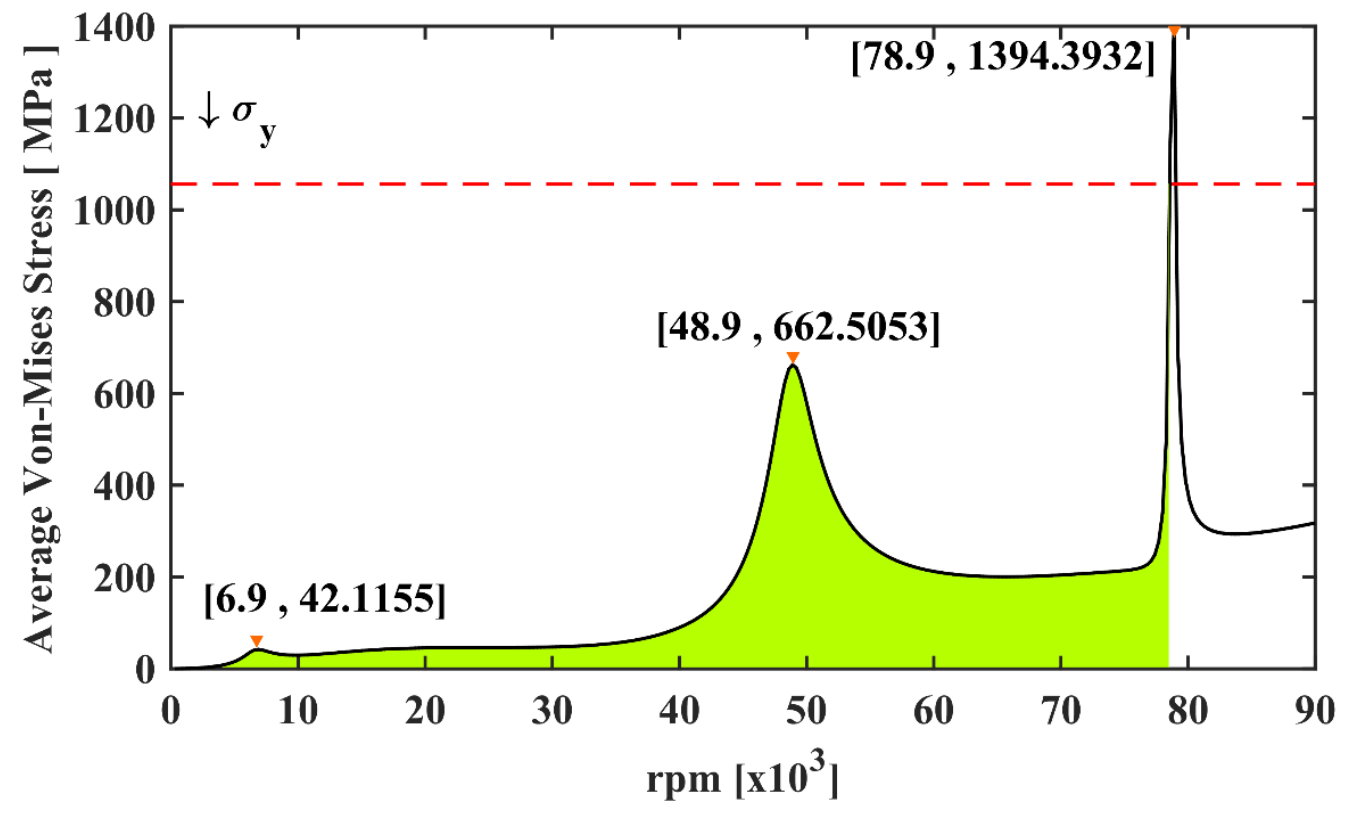

Figure 12. Shaft speed vs average Von-Mises Stress for AlC $0.4 \mathrm{CoCrFeNi}$

Şekil 12. AlC0.4CoCrFeNi için şaft hızına karşıllı gelen ortalama Von-Mises Gerilmesi

The frequency response results in Figure 12 depicts that the first resonance frequency and the stress corresponding to it are $6900 \mathrm{rpm}$ and $42.115 \mathrm{MPa}$ for $\mathrm{AlC} 0.4 \mathrm{CoCrFeNi}$ high entropy alloy material, respectively. As seen from the figure, the impeller does not meet with the plastic deformation up to the frequency $78560 \mathrm{rpm}$. Besides these, it can be inferred that when the rotational speed is higher than $78560 \mathrm{rpm}$ the stresses arise over the yield strength of $\mathrm{AlC} 0.4 \mathrm{CoCrFeNi}$ high entropy alloy material. 


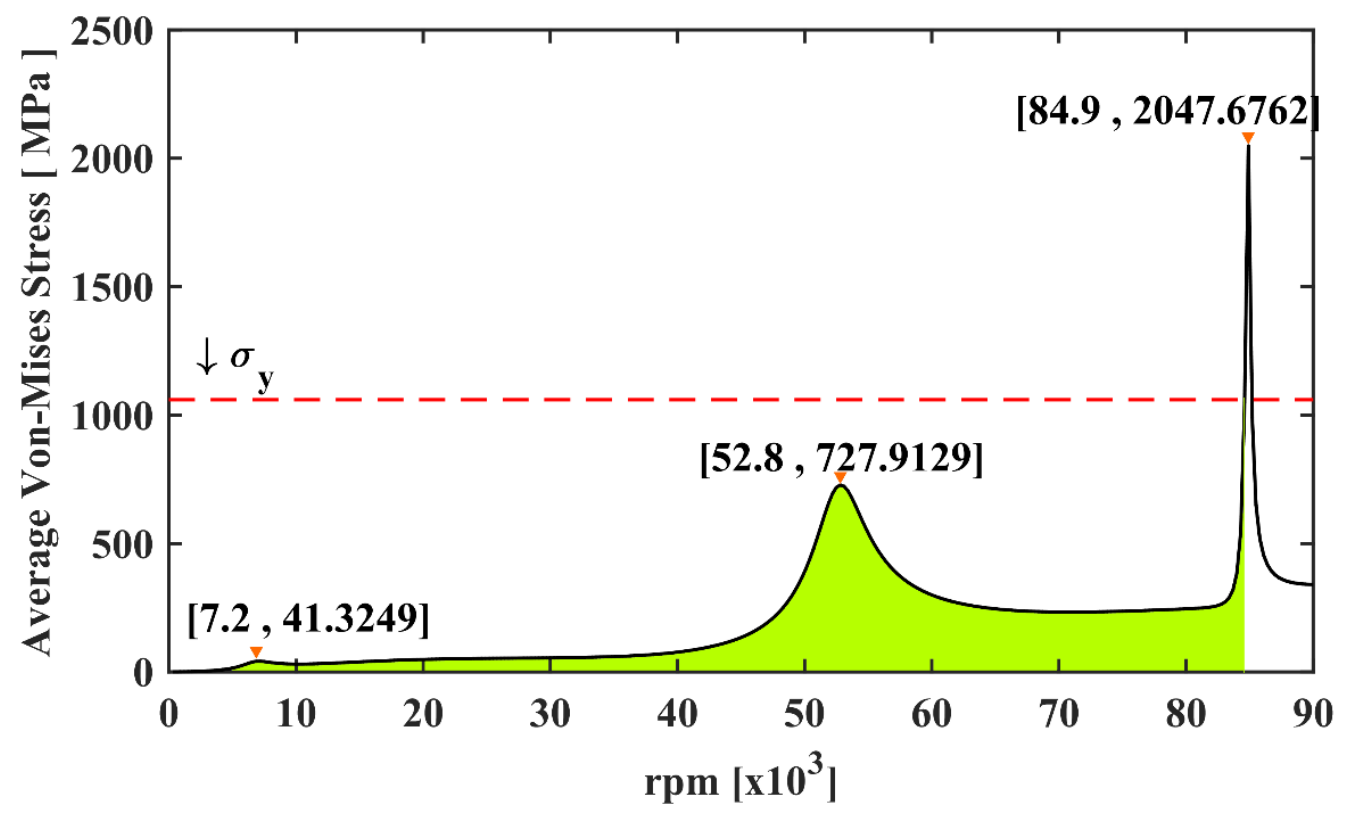

Figure 13. Shaft speed vs average Von-Mises Stress for AlC $0.5 \mathrm{CoCrFeNi}$

Şekil 13. AlC0.5CoCrFeNi için şaft hizına karşıllı gelen ortalama Von-Mises Gerilmesi

The results in Figure 13 display that the first resonance frequency and the stress corresponding to it are $7200 \mathrm{rpm}$ and $41.3249 \mathrm{MPa}$ for AlC $0.5 \mathrm{CoCrFeNi}$ high entropy alloy material, respectively. As it can be seen from the figure, the impeller does not encounter the plastic deformation up to the frequency $84600 \mathrm{rpm}$. Also, it can be concluded that when the rotational speed is higher than $84600 \mathrm{rpm}$ the stresses go up over the yield strength of $\mathrm{AlC} 0.5 \mathrm{CoCrFeNi}$ high entropy alloy material.

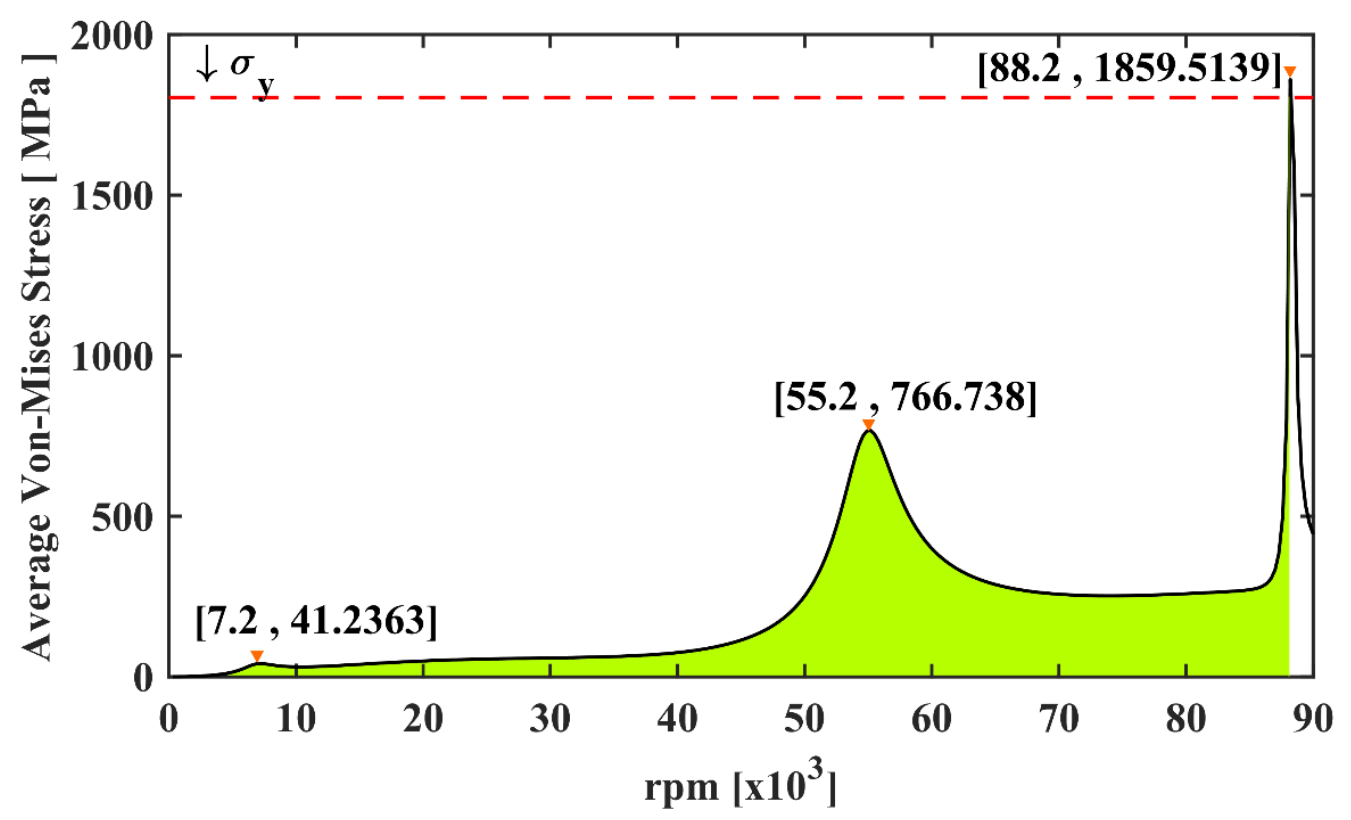

Figure 14. Shaft speed vs average Von-Mises Stress for AlCoCrFeMo0.1Ni

Şekil 14. AlCoCrFeMoO.1Ni için şaft hızına karşılık gelen ortalama Von-Mises Gerilmesi

As shown in Figure 14, the first resonance frequency and the stress corresponding to it are $7200 \mathrm{rpm}$ and 41.2363 MPa for AlCoCrFeMo0.1Ni high entropy alloy material, respectively. From the figure above we can see that, the impeller does not undergo plastic deformation up to the frequency $88190 \mathrm{rpm}$. On the other hand, when the rotational speed is higher than $88190 \mathrm{rpm}$ the stresses go up over the yield strength of $\mathrm{AlCoCrFeMo0.1Ni} \mathrm{high}$ entropy alloy material. 


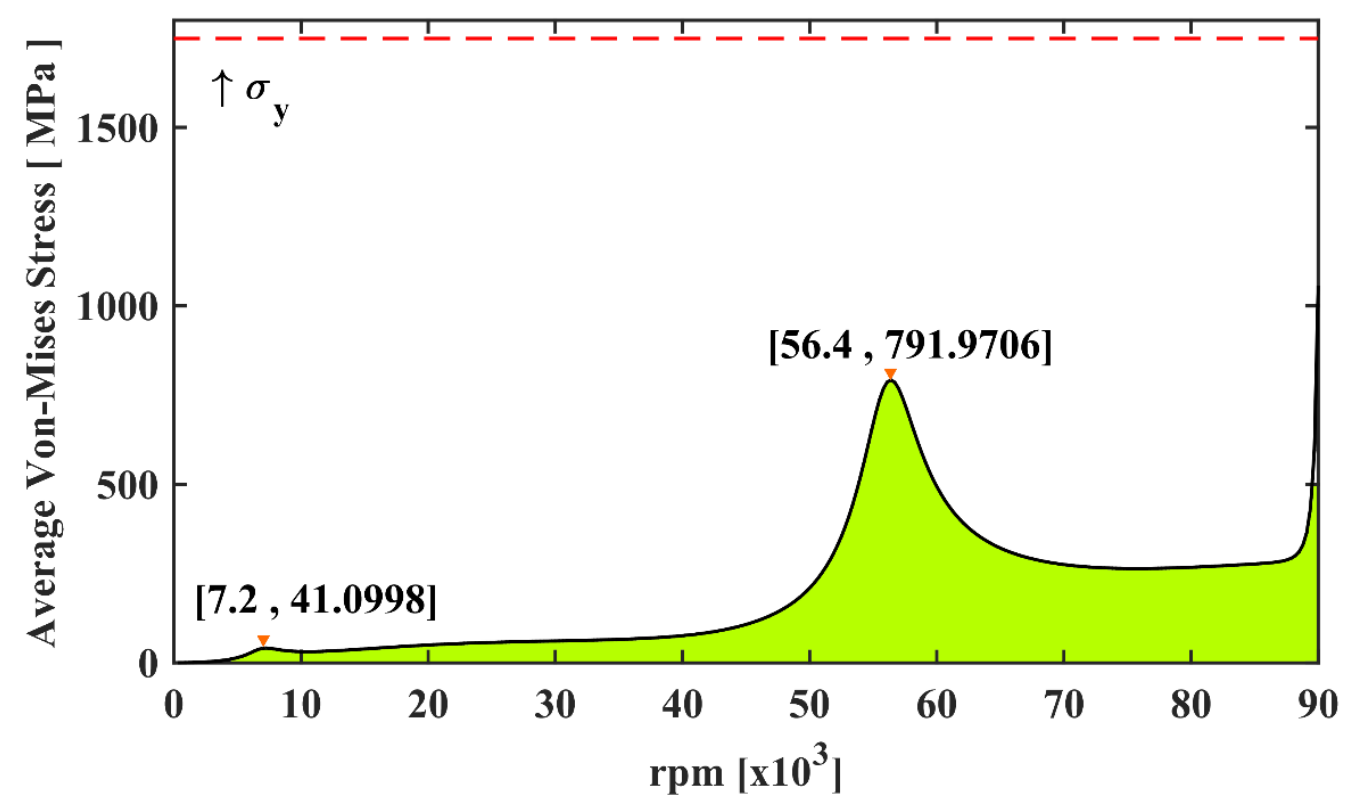

Figure 15. Shaft speed vs average Von-Mises Stress for AlCrFeNiMo0.5

Şekil 15. AlCrFeNiMo0.5 için şaft hızına karşıllı gelen ortalama Von-Mises Gerilmesi

As it can be seen from Figure 15, the first resonance frequency and the stress corresponding to it are $7200 \mathrm{rpm}$ and $41.0998 \mathrm{MPa}$ for $\mathrm{AlCrFeNiMo0.5}$ high entropy alloy material, respectively. As shown in Figure 15, the impeller does not subject to plastic deformation up to the frequency $90000 \mathrm{rpm}$ because all stress results are under the yield strength of $\mathrm{AlCrFeNiMo0.5} \mathrm{high} \mathrm{entropy} \mathrm{alloy}$ material. Another finding is that the impeller is reliable in the frequency sweep of 0 to $1500 \mathrm{~Hz}$ (90000 rpm).

Considering all the Figures from 6 to 15 (Figure 615) where the stress responses are given, it can be seen that stress responses of the second resonant frequency are greater than the stress responses of the first resonant frequency. This is because stress results are to be related to an unbalanced force that is proportional to the square of the speed of the rotating shaft. The second resonant frequency which creates a greater unbalance force is greater than the first resonant frequency, accordingly, the stress values also increase.

To make clear the frequency response results; the bar charts are plotted for all the different high entropy alloy materials. Here the results are given with the following non-dimensional percentagestress ratio (see Equation 3), $\xi$, denoting VonMisses stress to yielding strength ratio.

$$
\xi=100 \times \frac{\sigma_{v m}}{\sigma_{y}}
$$




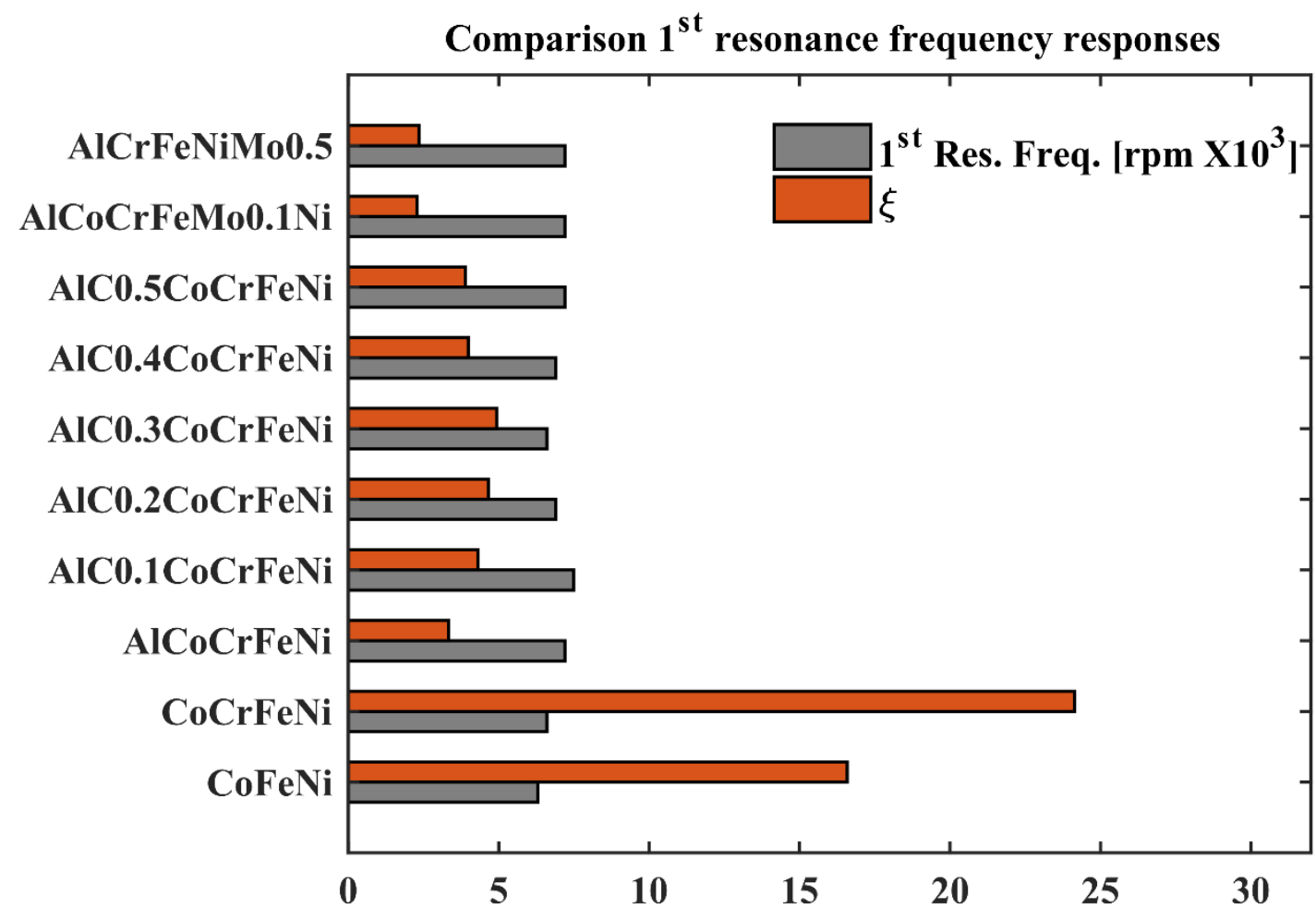

Figure 16. Comparison $1^{\text {st }}$ resonance frequency responses.

Şekil 16. 1. rezonans frekans cevaplarının karşılaştııılması.

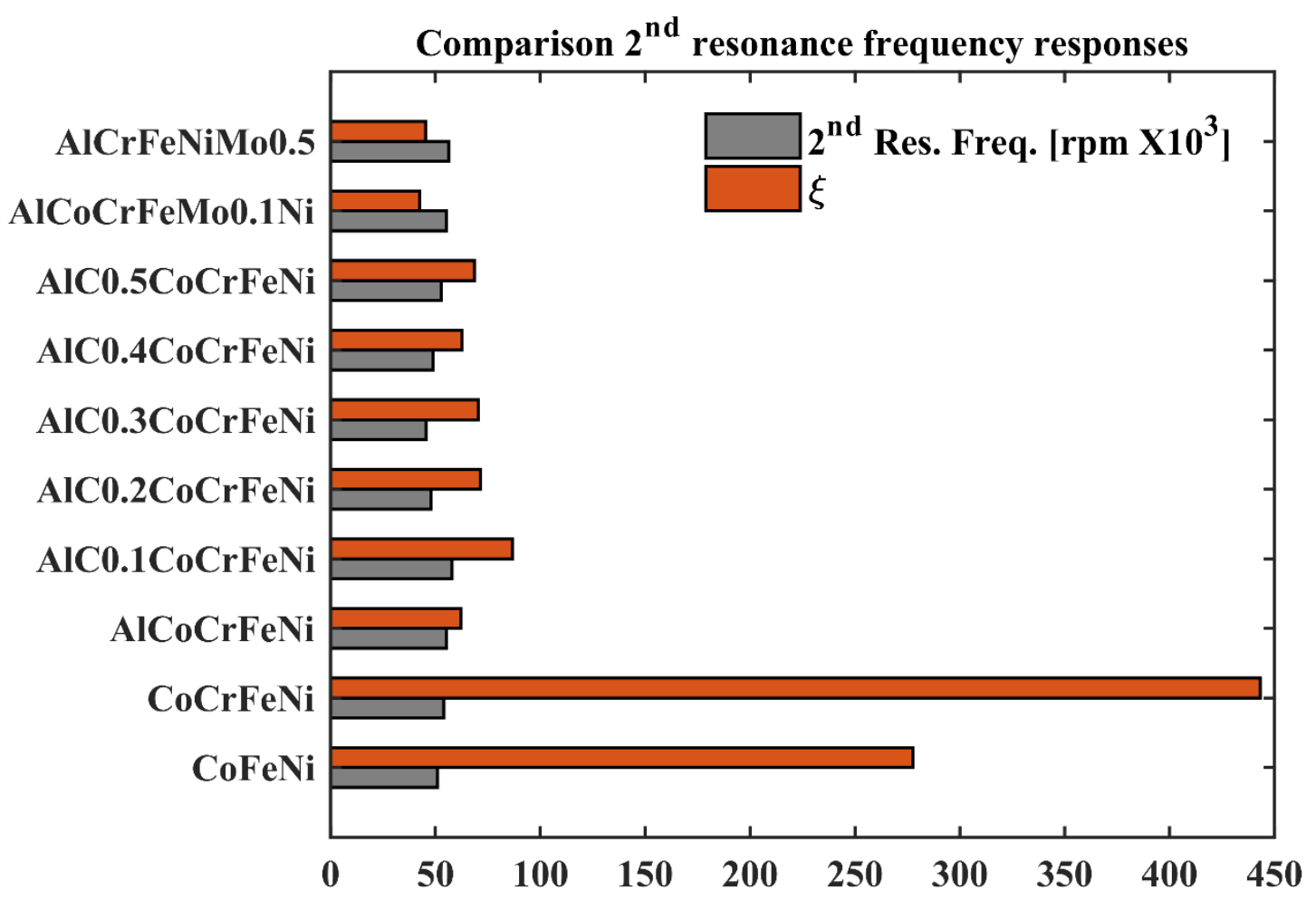

Figure 17. Comparison $2^{\text {nd }}$ resonance frequency responses.

Şekil 17. 2. rezonans frekans cevaplarının karşılaştırılması.

From Figure 16, it can be seen that by far the greatest stress-percentage ratio $(\xi=24.14)$ value in first resonance frequencies is for $\mathrm{CoCrFeNi} \mathrm{high}$ entropy alloy material. Also, it can be seen that by far the lowest stress-percentage ratio $(\xi=2.29)$ value in first resonance frequencies is for $\mathrm{AlCoCrFeMo0.1Ni} \mathrm{high} \mathrm{entropy} \mathrm{alloy} \mathrm{material.}$

The results in Figure 17 displays that by far the greatest stress-percentage ratio $(\xi=443.20)$ value 
in second resonance frequencies is for $\mathrm{CoCrFeNi}$ high entropy alloy material. On the other hand, it can be seen that by far the lowest stress-percentage ratio $(\xi=42.50)$ value in second resonance frequencies is for $\mathrm{AlCoCrFeMo0.1Ni} \mathrm{high} \mathrm{entropy}$ alloy material.

\section{Conclusion}

\section{Sonuç}

This study aims to inspect how harmonic responses of an impeller of a gas turbine engine when are modelled with high entropy alloy materials are influenced. Therefore, the finite element model of the impeller is created primarily for harmonic response analysis that gives the steady-state response corresponding to time-harmonic loads. Then Von-Mises stress responses versus to frequencies are calculated by using the normal and shear stresses computed in the harmonic analyses.

The results show that by far the greatest percentage ratio, $\xi=24.14$, is in CoCrFeNi high entropy alloy material for first resonance frequencies. On the other hand, calculations present that by far the lowest percentage ratio is, $(\xi=2.29)$, in

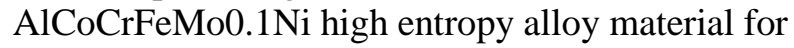
first resonance frequencies. Another finding is that by far the greatest percentage ratio is, $\xi=443.20$, in $\mathrm{CoCrFeNi}$ high entropy alloy material for second resonance frequencies. Furthermore, the lowest percentage ratio is observed $(\xi=42.50)$ in

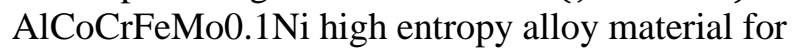
second resonance frequencies. Moreover, when compared Von Mises stresses obtained in the analyses, we can see that the greatest Von-Mises stress is, (2286.7813 MPa), for AlCoCrFeNi high entropy alloy material.

\section{Author contribution Yazar katkısı}

Serkan Guler: Conceptualization, Methodology, Resources, Software, Investigation, Validation, Writing - original draft, Writing - review \& editing.

\section{Declaration of ethical code}

Etik beyanı

The author of this article, declares that the material and the methods used in this study do not require ethical committee approval and/or special legal permission.

\section{Conflicts of interest \\ Çıkar çatışması beyanı}

The authors declare that they have no known competing financial interests or personal relationships that could have appeared to influence the work reported in this paper.

\section{Kaynaklar \\ References}

Bishop, R. E. D. (1959). The vibration of rotating shafts, Journal Mechanical Engineering Science 1(1). https://doi.org/10.1243/JMES_JOUR_1959_001 _024_02

Christensen, R. M., (2013). The theory of materials failure. Croydon- London, Oxford University Press.

Conway, P. L. J. (2018). Structure and stability of new types of lightweight high entropy and compositionally complex alloys $[\mathrm{Ph}$. D. thesis, The University of New South Wales School of Materials Science and Engineering].

Efe-Ononeme, O. E., Ikpe, A. E., \& Arievie, G. O. (2018). Modal analysis of conventional gas turbine blade materials (Udimet 500 and in 738) for industrial applications. Journal of Engineering Technology and Applied Sciences, $3(2)$, 119-133. https://doi.org/10.30931/jetas.452857

Erdoğan, A., \& Zeytin, S. (2019). High entropy alloys: principles and alloy design. Omer Halisdemir University Journal of Engineering Sciences, $8(2), \quad 1160-1178$. https://doi.org/10.28948/ngumuh.517876

Ertas, B. H. (2005). Rotordynamic force coefficients of pocket damper seals [Ph.D. thesis, Texas A\&M University].

Fernandes, R., El-Borgi, S., Ahmed, K., Friswell, M. I., \& Jamia, N. (2016). Static fracture and modal analysis simulation of a gas turbine compressor blade and bladed disk system. Advanced Modeling and Simulation in Engineering Sciences, $3(30)$, 1-23. https://doi.org/10.1186/s40323-016-0083-7

Fujieda, T., Kuwabara, K., Hirota, M., Aota K., Kato, T., Chiba, A., Koizumi, Y., \& Yamanaka, K. (2018). High entropy alloy member, method for producing alloy member, and product using alloy member. European patent EP 3392359A1.https://data.epo.org/publicationserver/rest/v1.0/publication dates/20181024/patents/EP3392359NWA1/doc ument.pdf (Visited on December. 18, 2020). 
Geantă, V., Voiculescu, I., Stefănoiu, R., Chereches, T., Zecheru, T., Matache, L., \& Rotariu, A. (2018). Dynamic impact behaviour of high entropy alloys used in the military domain, IOP Conf. Series: Materials Science and Engineering, 374, 012041. https://doi.org/10.1088/1757899X/374/1/012041

George, E. P., Curtin, W. A., \& Tasan, C. C. (2020). High entropy alloys: A focused review of mechanical properties and deformation mechanisms. Acta Materialia, 188, 435-474. https://doi.org/10.1016/j.actamat.2019.12.015

George, E.P., Raabe D., \& Ritchie R.O. (2019). High entropy alloys. Nature Reviews Materials, 4, 515-534. https://doi.org/10.1038/s41578-019$0121-4$

Gludovatz, B., Hohenwarter, A., Catoor, D., Chang, E. H., George, E. P., \& Ritchie, R. O. (2014). A fracture-resistant high-entropy alloy for cryogenic applications. Science, 345(6201), 1153-1158.

https://doi.org/10.1126/science.1254581

Gondhalekar, A. A. (2019). Design and Development of Light Weight High Entropy Alloys [Master thesis, Jönköping School of Engineering].

Gorsse, S., Nguyen, M.H., Senkov, O.N., \& Miracle, D.B. (2018). Database on the mechanical properties of high entropy alloys and complex concentrated alloys. Data in Brief, 21, 26642678. https://doi.org/10.1016/j.dib.2018.11.111

Gunter, E. J. Jr. (1966). Dynamic stability of rotorbearing systems. NASA SP-113, Washington, D.C.

Gülen, S. C. (2019). Gas turbines for electric power generation. New York, Cambridge University Press.

Koželj, P., Vrtnik, S., Jelen, A., Jazbec, S., Jagličić, Z., Maiti, S., Feuerbacher, M., Steurer, W., \& Dolinšek, J. (2014). Discovery of a superconducting high-entropy alloy. Physical Review Letters, 113, 107001-1-107001-5. https://doi.org/10.1103/PhysRevLett.113.10700 1

Kumar, M. S. (2011). Rotor dynamic analysis using ANSYS. IUTAM Symposium on emerging trends in rotor dynamics, IUTAM bookseries, 1011, Springer. https://doi.org/10.1007/978-94-0070020-8_14

Miracle, D. B. \& Senkov, O. N. (2017). A critical review of high entropy alloys and related concept. Acta Materilia, 122, 448-511. https://doi.org/10.1016/j.actamat.2016.08.081
Mudau T., \& Field, R. M. (2018). Rotordynamic analysis of the AM600 turbine-generator shaftline. Energies, 11(12), 3411. https://doi.org/10.3390/en11123411

Rao, J. S. (2011). Rotor Dynamics Methods. In: History of Rotating Machinery Dynamics, History of Mechanism and Machine Science, 20. Springer.

Rao, S. S. (2010). The Finite Element Method in Engineering ( $5^{\text {th }}$ Edition). Oxford: BH Elsevier.

Schomerus, A. (2007). Investigation of LabView as a tool for rotordynamic measurements and diagnostics, Turbomachinery Research Consortium Report TRC-RD-1-07, Texas A\&M University.

Theory Reference for the Mechanical APDL and Mechanical Applications, ANSYS Release12.1. (2010, March 10) http://www1.ansys.com/customer/content/docu mentation/121/ans_thry.pdfs.

Thompson, M. K., \& Thompson, J.M. (2017). ANSYS Mechanical APDL for Finite Element Analysis. BH Elsevier, Oxford: BH Elsevier.

Vance J. M., \& Laudadio, F. J. (1984). Experimental measurement of Alford's force in axial flow turbomachinery, ASME Journal of Engineering for Gas Turbines and Power, 106(3), 585-590. https://doi.org/10.1115/1.3239610

Vance, J. M., \& French, R. S. (1986). Measurement of torsional vibration in rotating machinery, Journal of Mechanisms, Transmissions, and Automation in Design, 108(4), 565-577. https://doi.org/10.1115/1.3258771

Vance, J., Zeidan, F., \& Murphy, B. (2010). Machinery Dynamics and Rotordynamics. John Wiley \& Sons.

Virdi, P. S., Khan, M. S., Pereira, N., Suresh, K.V., \& D'Silva, R. S. (2017). Design and fabrication of major components of turbojet engine, Energy and Power, 7(5), 130-135. doi:10.5923/j.ep. 20170705.02

Ye, Y.F., Wang, Q., Lu, J., Liu, C.T., \& Yang, Y. (2016). High-entropy alloy: challenges and prospects. Materials Today, 19(6), 349-362. https://doi.org/10.1016/j.mattod.2015.11.026

Youssef, K. M., Zaddach, A. J., Niu, C., Irving, D. L., \& Koch, C. C. (2014). A novel low-density, highhardness, high-entropy alloy with close-packed single-phase nanocrystalline structures. Materials Research Letters, 3(2), 95-99. https://doi.org/10.1080/21663831.2014.985855 